\title{
Solubility enhancement of poorly aqueous soluble novel drug using natural gum as carriers
}

\author{
Manoj Kumar Katual ${ }^{1 *}$, Gurfateh Singh $^{2}$, S L Harikumar ${ }^{3}$ \\ ${ }^{\mathbf{1}}$ Associate Professor and Head, ${ }^{\mathbf{D}}$ Dean \& Associate Professor, ${ }^{\mathbf{3}}$ Professor \& Registrar, ${ }^{\mathbf{1}}$ Rayat-Bahra Institute of Pharmacy, Education City, \\ Hoshiarpur, Punjab, ${ }^{2}$ University School of Pharmaceutical Sciences, Rayat-Bahra University, Mohali, Punjab, ${ }^{3}$ Central University of \\ Jharkhand. Ranchi, Jharkhand, India
}

*Corresponding Author: Manoj Kumar Katual

Email: manojkumar.katual@gmail.com

\begin{abstract}
The current article is based on the concept to enhance the solubility and dissolution rate of a model drug, Rosuvastatin Calcium, which is BCS class-II drug with anti-hyperlipidemic potential. The reported bioavailability from oral route of drug is only $20 \%$. So aim of current study is to improve the solubility and dissolution rate of a poorly water-soluble drug Rosuvastatin Calcium, by solid dispersion technique. Physical mixtures and solid dispersions were prepared using natural polymers A. Marmelos in different to drug to carrier ratios. Prepared formulations were characterized in solid state by FTIR analysis, powder X-ray diffraction, Scanning electron microscopy and in-vitro dissolution study. Solid state characterizations indicated the Rosuvastatin Calcium was present in amorphous form and entrapped in polymer matrix. In contrast to the very slow dissolution rate of pure Rosuvastatin Calcium, the dispersion of the drug in the polymers considerably enhanced the dissolution rate. The mixtures of solid dispersion and excipients were evaluated for pre-compression parameters. After then fast dissolving tablets were prepared by direct compression technique. The formulated tablets were evaluated by post compression parameters. In-vitro drug release performance of the developed formulations was investigated.
\end{abstract}

Keywords: Solid Dispersion. Natural gums, Anti-lipidemic activity.

\section{Introduction}

Solubility is the property of a solid, liquid, or gaseous chemical substance called solute to dissolve in a solid, liquid, or gaseous solvent to form a homogeneous solution of the solute in the solvent. The solubility of a substance fundamentally depends on the solvent used as well as on temperature and pressure. Absorption of a drug through the oral route involves its dissolution from the formulation into gastric and/ or intestinal fluids followed by its permeation through gastrointestinal cell membranes and finally into the systemic circulation. Oral solid dosage forms are one of the most commonly used formulation types having multiple benefits over other formulations/routes. However, the challenge for a pharmaceutical scientist lies in the fact that dissolution of a drug from an oral solid formulation (a key factor in drug absorption) is dependent on the aqueous solubility of the drug. Therefore, a drug with poor aqueous solubility would exhibit dissolution rate limited absorption and similarly a drug possessing poor membrane permeability undergo permeation rate limited absorption. ${ }^{1}$

\section{Process of solubilization}

Solubilization of poorly soluble drugs is a frequently encountered challenge in screening studies of new chemical entities as well as in formulation design and development. A number of methodologies can be adapted to improve solubilization of poor water soluble drug and further to improve its bioavailability. Orally administered drugs completely absorb only when they show fair solubility in gastric medium and such drugs shows good bioavailability. Bioavailability depends on several factors, drug solubility in an aqueous environment and drug permeability through lipophillic membranes being the important ones. ${ }^{2,3}$

\section{Drug \& excipient profile}

Rosuvastatin calcium is a statin having antilipidemic activity that synthetically inhibits the Hydroxymethylglutaryl-COA-reductase enzyme. Rosu cal is a noval active substance is a white yellowish powder which shows no polymorphism. It belongs to a new generation of methane-sulphonamide pyrimidine and $\mathrm{N}$-methane sulfonyl pyrrole-substituted 3,5-dihydroxy-heptenoates. Most of the statin drugs lack systemic bioavailability due to their absorption profile. So in order to reach effective therapeutic concentration, large doses of drugs in frequent intervals of time are needed to be administerted; this may lead to induce adverse effects and may lack patient compliance. Gum is obtained from fruits of A. marmelos belonging to family Rutaceae. In many investigations high aqueous solubility of A.marmelos gum has been evaluated. Gum karaya, or sterculia gum, is the dried exudates of sterculia urens.

\section{Objectives}

The objective of this research work was to increase the solubility of the Rosuvastatin calcium by increasing its release rate with the help of various carriers and also formulating fast dissolving tablets of the prepared solid dispersion of API. The mathematical tools to be employed for the bio-statistical evaluation of the formulations.

\section{Experimental \\ Preparation of Aegle Marmelos gum}

$1 \mathrm{~kg}$ fruit was obtained and gum extract from fruits manually. Dried at room temperature for 3 days. After then crush in mortar and powder pass through sieve no.\#85.Gum was solublised in distilled water and wash with acetone upto $150 \mathrm{ml}$. precipitation occur then filter and filtrate gum dried 
at 30 oc for 1 day. Light brown color of A.Marmelos was obtained. ${ }^{4}$

\section{Preparation of formulation}

Preparation of physical mixtures of Rosuvastatin Calcium with three different carriers

Physical mixture were prepared by mixing accurate weight of Rosuvastatin Calcium with carriers in drug to polymers ratio $1: 0.50,1: 0.75,1: 1 \quad(\mathrm{~A} 1, \mathrm{~B} 1, \mathrm{C} 1, \mathrm{~A} 2, \mathrm{~B} 2, \mathrm{C} 2, \mathrm{~A} 3, \mathrm{~B} 3, \mathrm{C} 3)$ respectively. The physical mixture was pulverizes and then mixed thoroughly in mortar with a pestle until homogenous mixture was obtained. The mixture was passed through sieve no. \#85 collected and stored in close container away from humidity until use.

\section{Preparation of solid dispersion of Rosuvastatin Calcium} with polymers

Solid dispersions of Rosuvastatin Calcium with polymers were prepared by the solvent evaporation method.

Table 1: Ingredients used in the preparation of solid dispersions

\begin{tabular}{|c|c|c|c|c|c|}
\hline $\begin{array}{c}\text { Drug: Polymer } \\
\text { Ratio }\end{array}$ & $\begin{array}{c}\text { Rosuvastatin Calcium } \\
(\mathbf{m g})\end{array}$ & $\begin{array}{c}\text { TPGS } \\
(\mathbf{m g})\end{array}$ & $\begin{array}{c}\text { A.marmelos } \\
(\mathbf{m g})\end{array}$ & $\begin{array}{c}\text { MGK } \\
(\mathbf{m g})\end{array}$ & Solvent amount \\
\hline $1: 0.5$ & 500 & 200 & 250 & 250 & 100 \\
\hline $1: 0.75$ & 500 & 375 & 375 & 375 & 100 \\
\hline $1: 1$ & 500 & 500 & 500 & 500 & 100 \\
\hline
\end{tabular}

\section{In-vitro dissolution studies of rosuvastatin calcium, physical mixtures and solid dispersions}

Rosuvastatin Calcium, physical mixtures and solid dispersion equivalent to $100 \mathrm{mg}$ of Rosuvastatin Calcium were used for studying the rate and extent of drug dissolution. The study was performed using USP Type II (Paddle type).

\section{Formulation of fast dissloving tablets of rosuvastatin calcium}

Direct compression method was used to prepare 10mg dose strength Rosuvastatin Calcium fast dissolving tablets. The materials were accurately weighed and mixed together to obtain homogeneous or uniform mass mixture which was sieved through mesh size \#42. Sodium Starch Glycolate (SSG) was used as superdisintegrant. Micro-crystalline cellulose (MCC) was used as directly compressible material ${ }^{5}$ and magnesium stearate was used as tablet lubricant. Talc as glident or anticaking agent.

\section{Results}

pre-formulation studies

\section{Physical Appearance}

Rosuvastatin Calcium is a yellowish white powder with crystalline nature

\section{Melting point}

Melting point of the drug was found to be $119^{\circ} \mathrm{C}$ which is agreement with the reported value $\left(122^{\circ} \mathrm{C}\right)$

\section{Analytical Study}

Determination of absorbance of Rosuvastatin Calcium

Rosuvastatin Calcium was estimated at UV-maxima of $243.2 \mathrm{~nm}$ in water+methanol, pH 6.8 \& pH 7.4 phosphate buffers using UV-Visible double beam spectrophotometer. The scanning of the drug was done in the range of nm as shown in figure.

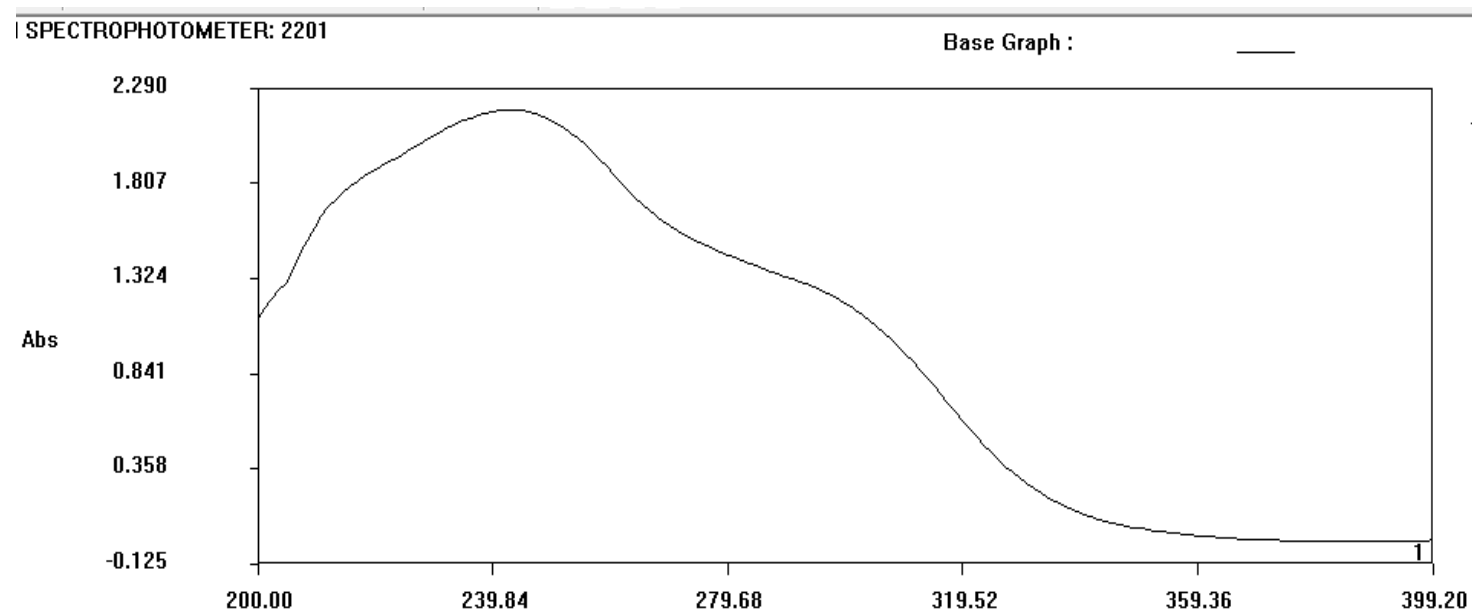

Fig. 1: Calibration curve of Rosuvastatin Calcium showing maximum absorbance at 243.2nm. 
Table 2: Absorbance of Rosuvastatin calcium in three different solvents

\begin{tabular}{|c|c|c|c|}
\hline Concentration $(\boldsymbol{\mu g} / \mathbf{m l})$ & PBS pH 6.8 ${ }^{*} \mathbf{S D}$ & $\mathbf{P B S} \mathbf{~ p H ~ 7 . 4} * \mathbf{* S D}$ & $\begin{array}{c}\text { Distilled water } \\
\text { +Methanol } * \mathbf{S D}\end{array}$ \\
\hline 2 & 0.014 & 0.059 & 0.010 \\
\hline 4 & 0.138 & 0.17 & 0.155 \\
\hline 6 & 0.285 & 0.3 & 0.285 \\
\hline 8 & 0.434 & 0.461 & 0.433 \\
\hline 10 & 0.557 & 0.589 & 0.554 \\
\hline 12 & 0.720 & 0.721 & 0.684 \\
\hline
\end{tabular}

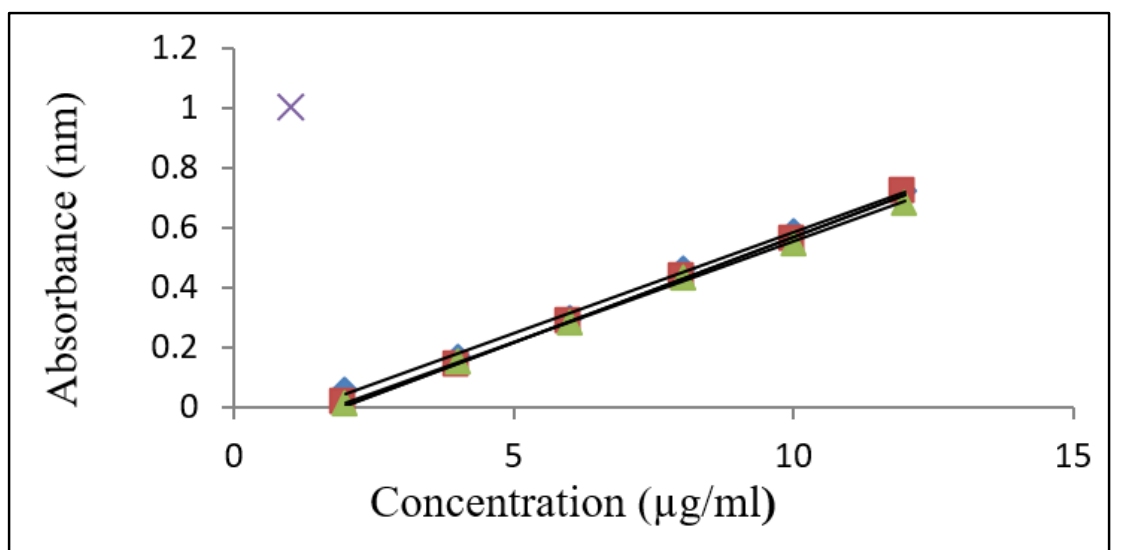

Fig. 2: Calibration plot of Rosuvastatin Calcium in different solvents

Interday and Intraday precision

Interday precision was found to be in the range of 0.1-0.6 and intraday precision was found to be 0.09 to 0.6

Table 3: Interday and Intraday precision data and statistical results

\begin{tabular}{|l|c|c|c|c|c|c|}
\hline Solvent & $\begin{array}{c}\text { Absorbance } \\
\text { (intraday) } \\
(\boldsymbol{\mu g} / \mathbf{m l})\end{array}$ & $\begin{array}{c}\text { Absorbance } \\
\text { (interday) } \\
(\boldsymbol{\mu g} / \mathbf{m l})\end{array}$ & $\begin{array}{c}\text { Interday } \\
(\boldsymbol{\%} \text { age conc. }) \\
\mathbf{\pm S D}\end{array}$ & $\begin{array}{c}\text { Intraday } \\
(\boldsymbol{\%} \text { age conc) } \\
\mathbf{\pm S D}\end{array}$ & $\begin{array}{c}\text { Interday } \\
(\boldsymbol{\%} \mathbf{R S D})\end{array}$ & $\begin{array}{c}\text { Intraday } \\
(\boldsymbol{\%} \mathbf{R S D})\end{array}$ \\
\hline pH 6.8 & 0.720 & 0.721 & $98 \pm 0.005$ & $97.4 \pm 0.003$ & 0.195 & 0.654 \\
\hline pH 7.4 & 0.719 & 0.720 & $98.4 \pm 0.003$ & $98 \pm 0.002$ & 0.192 & 0.567 \\
\hline $\begin{array}{l}\text { Distilled water+ } \\
\text { Methanol }\end{array}$ & 0.685 & 0.684 & $99.3 \pm 0.004$ & $99.3 \pm 0.005$ & 0.506 & 0.096 \\
\hline
\end{tabular}

\subsubsection{Repeatability}

The repeatability mean concentration was found to be $0.693 \mu \mathrm{g} / \mathrm{ml}$

Table 4: Results of repeatability studies in different solvents

\begin{tabular}{|c|c|c|c|}
\hline $\begin{array}{l}\text { Concentration } \\
(\boldsymbol{\mu g} / \mathbf{m l})\end{array}$ & Absorbance (pH 6.8) & Absorbance (pH 7.4) & $\begin{array}{c}\text { Absorbance (Distilled water+ } \\
\text { Methanol) }\end{array}$ \\
\hline 12 & 0.722 & 0.720 & 0.684 \\
\hline 12 & 0.721 & 0.721 & 0.683 \\
\hline 12 & 0.720 & 0.720 & 0.683 \\
\hline 12 & 0.721 & 0.720 & 0.682 \\
\hline 12 & 0.720 & 0.720 & 0.684 \\
\hline 12 & 0.721 & 0.720 & 0.683 \\
\hline Mean & $0.721 \pm 0.0012$ & $0.720 \pm 0.0075$ & $0.683 \pm 0.0018$ \\
\hline SD & 0.0010 & 0.00170 & 0.00271 \\
\hline \%RSD & 0.17 & 0.54 & 0.44 \\
\hline
\end{tabular}




\section{Characterization of A.marmelos fruit gum}

Table 5: Characterization of A.marmelos fruit gum

\begin{tabular}{|l|c|}
\hline Parameters & A.marmelos \\
\hline Ash value & $82.1 \%$ \\
\hline Loss on drying & $3 \%$ \\
\hline Hydration capacity & 0.8870 .0054 \\
\hline
\end{tabular}

\section{Thin layer chromatography of A.marmelos}

Table 6: Thin layer chromatography of A.marmelos

\begin{tabular}{|l|c|c|c|}
\hline Solvent system & Ratio & Distance travelled & Rf value \\
\hline Methanol:glacial acetic acid: chloroform & $16: 10: 4$ & 8.6 & 0.89 \\
\hline n-butanol:acetic acid:water & $15: 10: 5$ & 6.5 & 0.543 \\
\hline Tolune:ethyl acetate: diethylamine & $5: 20: 5$ & 10.0 & - \\
\hline
\end{tabular}

Rf values 0.89 shows the presence of marmelosin constituents in gum which are responsible for enhancing solubility and 0.543 shows the presence of umbelliferone.

\section{Solubility Study}

Phase solubility

Table 7: Phase solubility studies of Rosuvastatin Calcium

\begin{tabular}{|l|c|c|c|}
\hline \multirow{2}{*}{ Concentration of Polymers $(\%$ w/v) } & \multicolumn{3}{|c|}{ Solubility (mg/ml) } \\
\cline { 2 - 4 } & TPGS & MGK & A.Marmelos \\
\hline 0.005 & 0.198 & 0.154 & 0.019 \\
\hline 0.5 & 0.601 & 0.328 & 0.291 \\
\hline 0.75 & 0.645 & 0.387 & 0.336 \\
\hline 50 & 0.731 & 0.432 & 0.398 \\
\hline 100 & 0.798 & 0.479 & 0.376 \\
\hline
\end{tabular}

Table 8: Percentage drug content of Rosuvastatin Calcium

\begin{tabular}{|l|c|c|c|}
\hline Drug+Polymer ratio & TPGS & MGK & A.Marmelos \\
\hline $1: 0.5$ & 79.61 & 78.46 & 53.09 \\
\hline $1: 0.75$ & 92.48 & 94.28 & 65.58 \\
\hline $1: 1$ & 99.79 & 97.79 & 66.08 \\
\hline
\end{tabular}

Drug dontent

The uniformity in the drug content ${ }^{11}$ for all the formulations was found to be within the limits of $90-100 \%$ and results are shown in Table 9.

\section{In -vitro dissolution studies}

The in vitro release profile of Rosuvastatin Calcium in $\mathrm{pH} 6.8$ phosphate buffer is shown in figure.

Table 9: Cumulative drug release of pure drug Rosuvastatin Calcium in $\mathrm{pH} 6.8$ phosphate buffer

\begin{tabular}{|c|c|}
\hline Time (min) & Pure Drug \% C.D.R \\
\hline 0 & 12.54 \\
\hline 5 & 25.84 \\
\hline 10 & 34.08 \\
\hline 15 & 35.11 \\
\hline 20 & 36.07 \\
\hline 30 & 36.14 \\
\hline
\end{tabular}




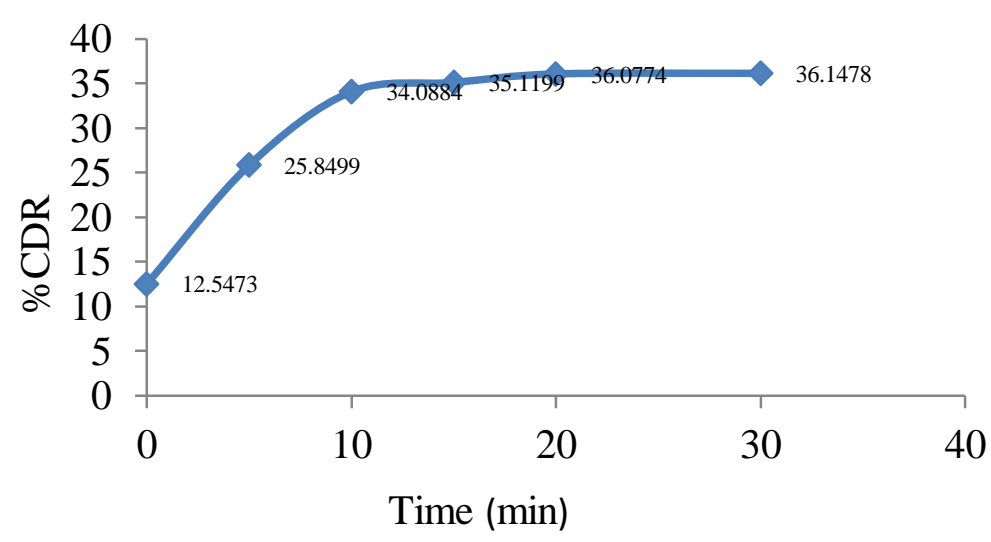

Fig. 3: Dissolution Profile of pure drug Rosuvastatin Calcium in pH 6.8 phosphate buffer

In Vitro dissolution of solid dispersions of Rosuvastatin Calcium and different polymers

Solid dispersion of Rosuvastatin Calcium in A.Marmelos, Gum karaya, TPGS containing three drug:polymer ratio (1:0.5,1:0.75,1:1) and using 6.8 phosphate buffer $900 \mathrm{ml}$ solvent were prepared. ${ }^{12-14}$

Table 10: Percentage cumulative drug release of solid dispersion of rosuvastatin calcium and A.Marmelos in different drug to polymer ratios

\begin{tabular}{|l|c|c|c|c|}
\hline \multirow{2}{*}{ S.No. } & \multirow{2}{*}{ Time (min) } & \multicolumn{3}{|c|}{ Percentage Cumulative Release \pm SD } \\
\cline { 3 - 5 } & & SD1 & SD2 & SD3 \\
\hline 1 & 0 & 40.49416901 & 33.64909859 & 31.34205634 \\
\hline 2 & 10 & 37.96120742 & 38.98215511 & 34.63957221 \\
\hline 3 & 20 & 40.24500639 & 41.51228849 & 37.1767078 \\
\hline 4 & 30 & 38.98687981 & 51.14839732 & 38.44637861 \\
\hline 5 & 45 & 41.26349206 & 48.8695484 & 39.7595806 \\
\hline 6 & 60 & 46.0826854 & 50.39338963 & 42.25353953 \\
\hline
\end{tabular}

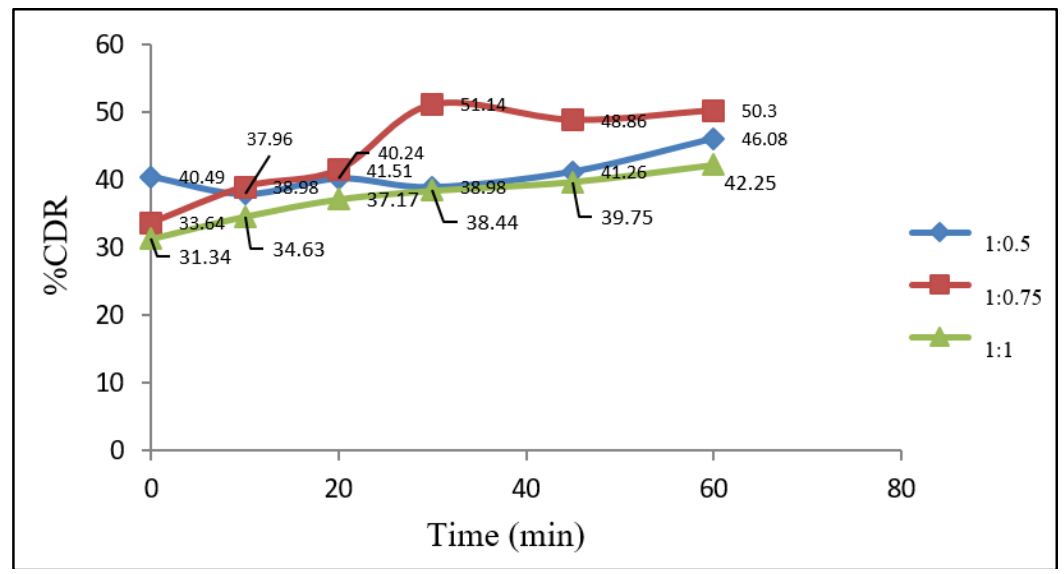

Fig. 4: Dissolution profile of solid dispersion of rosuvastatin calcium and A.Marmelos in different drug to polymer ratios

Thus, it was concluded from the studies that the solid dispersion technique has improved the dissolution rate of Rosuvastatin Calcium to a great extent. The dissolution form solid dispersions were greater than that from the pure drug and marketed formulation.

\section{Characterization of optimized solid dispersions}

\section{Fourier Transform Infrared Spectroscopy}

FT-IR spectra of TPGS, Drug, Physical mixtures and solid dispersions were recorded using

FT-IR spectrophotometer in below Figures respectively. Prominent peaks of spectral analysis shown in Table 11. 
Table 11: Spectral analysis of Rosuvastatin Calcium, TPGS, MGK, A.Marmelos, Physical Mixture with different polymers and optimized solid dispersion

\begin{tabular}{|l|c|c|c|c|c|c|c|}
\hline Pure Drug & TPGS & MGK & Marmelos & $\begin{array}{c}\text { Physical } \\
\text { Mixture } \\
\text { with } \\
\text { TPGS }\end{array}$ & $\begin{array}{c}\text { Physical } \\
\text { Mixture } \\
\text { with MGK }\end{array}$ & $\begin{array}{c}\text { Physical } \\
\text { Mixture with } \\
\text { A.Marmelos }\end{array}$ & $\begin{array}{c}\text { Optimized } \\
\text { Solid } \\
\text { Dispersion } \\
\text { with TPGS }\end{array}$ \\
\hline 3253.73 & 2868.65 & 3436.43 & 1544.36 & 3387.37 & 3462.42 & 2969.23 & 3385.18 \\
2931.64 & 1544.97 & 2967.03 & 1509.18 & 2869.91 & 2972.52 & 1543.37 & 2929.00 \\
1546.73 & 1509.10 & 2082.41 & 1435.45 & 1738.23 & 2087.91 & 1509.15 & 1546.96 \\
1509.27 & 1437.71 & 1634.66 & 1379.76 & 1544.30 & 1634.53 & 1435.65 & 1437.98 \\
1380.26 & 1379.22 & 1509.22 & 1333.98 & 1509.17 & 1382.20 & 1379.59 & 1381.08 \\
1227.50 & 1226.98 & 1382.00 & 1227.37 & 1436.20 & 1152.89 & 1151.13 & 1228.70 \\
1151.44 & 1102.01 & 1230.25 & 1151.08 & 1379.21 & 964.31 & 961.56 & 1116.82 \\
962.28 & 959.10 & 1154.29 & 961.88 & 1147.48 & 656.12 & 842.77 & 962.51 \\
843.26 & 842.36 & 964.68 & 900.82 & 959.20 & & 774.31 & 844.85 \\
750.04 & 774.24 & 776.00 & 773.83 & 843.43 & & & 775.41 \\
\hline
\end{tabular}

From the above observation it was evident that there was no major shifting in the frequencies of key functional groups. Hence the drug and polymers are compatible with each other. Hence IR showed absence of incompatibility between the Rosuvastatin Calcium and Polymers.

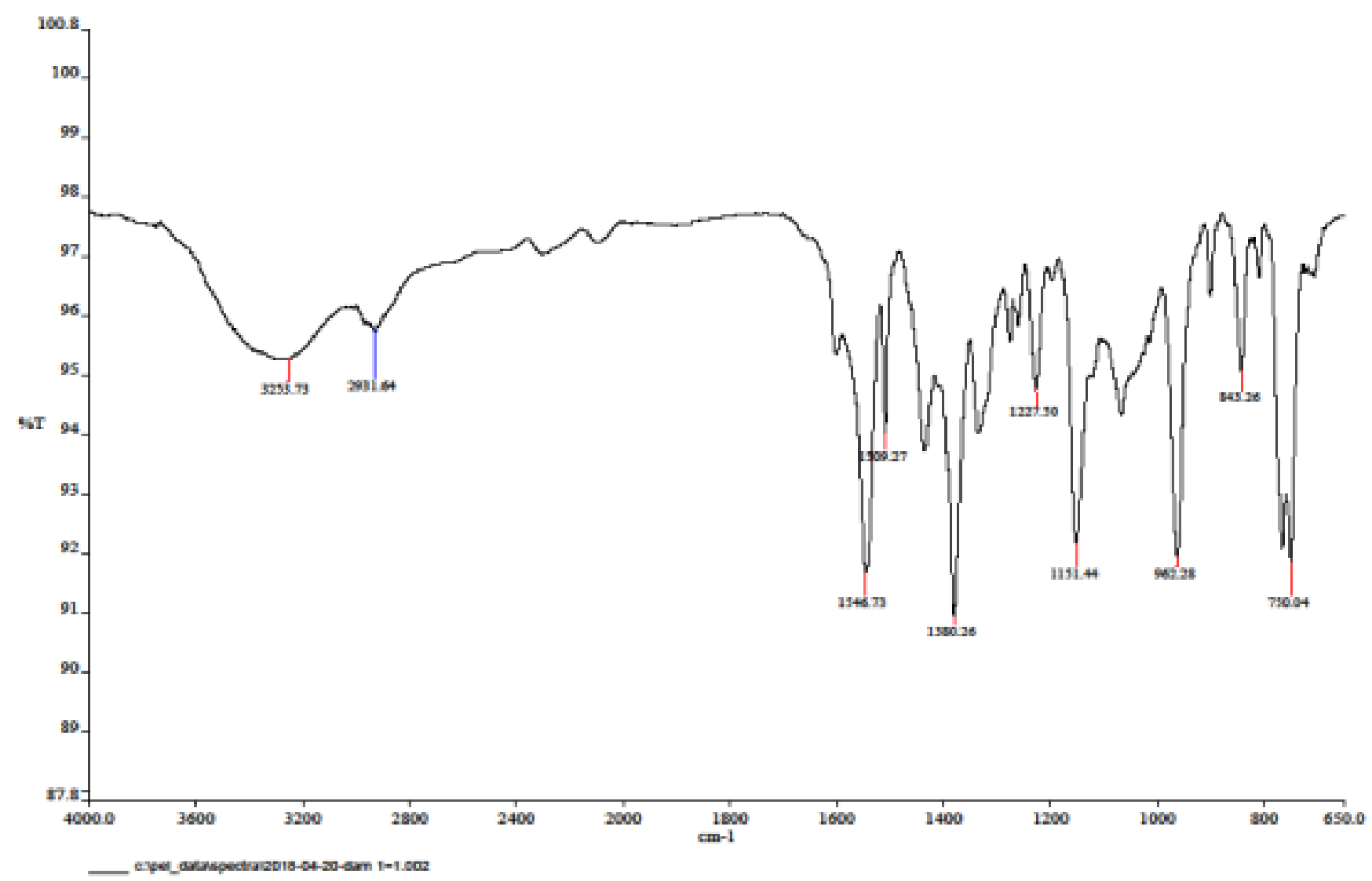

Fig. 5: Fourier transform infrared spectrum of Rosuvastatin Calcium 


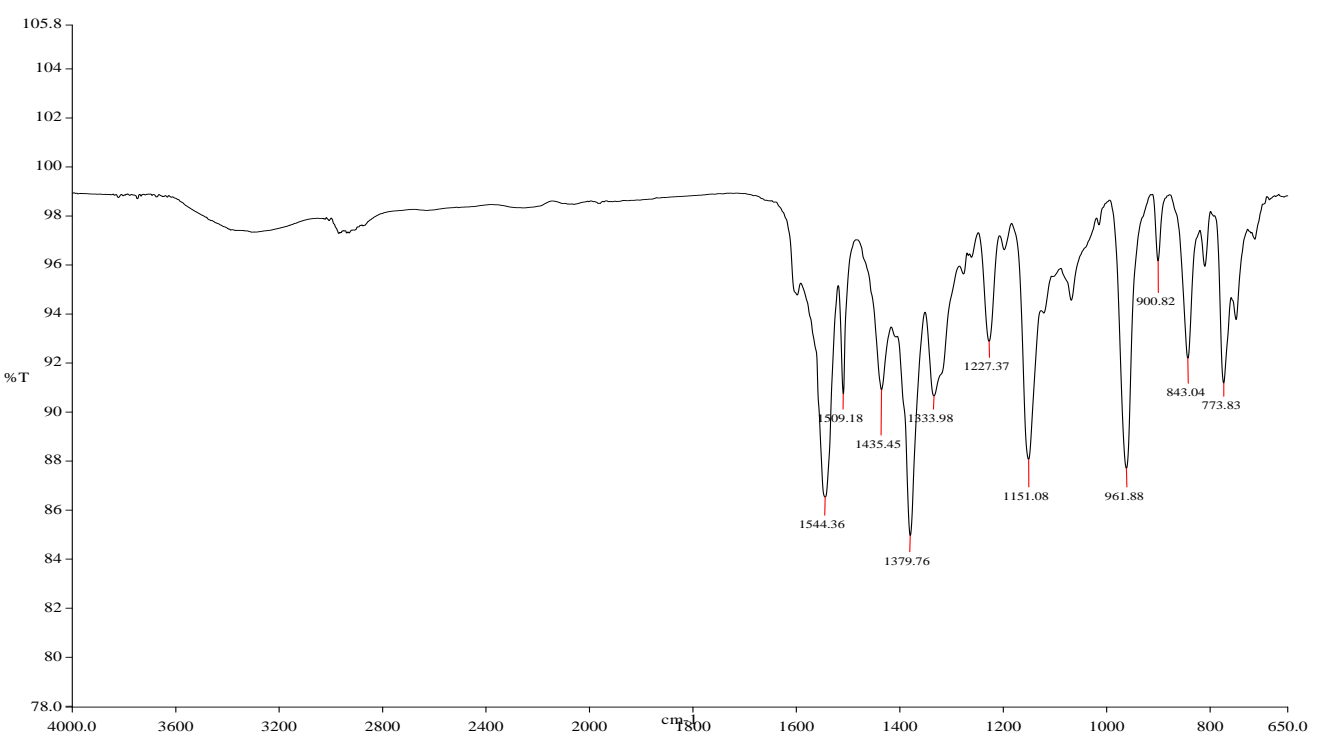

Fig. 6: Fourier transform infrared spectrum of A.Marmelos Gum

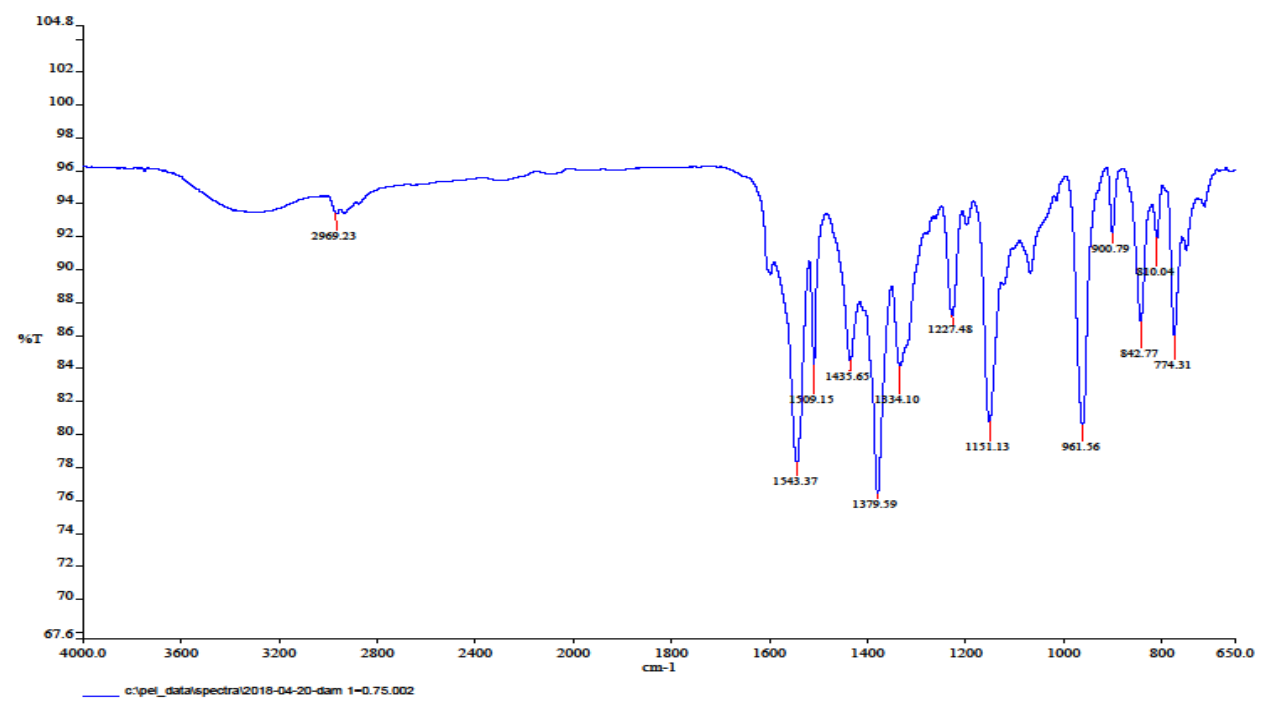

Fig. 7: Fourier transform infrared spectrum of Physical Mixture (Drug+ A.Marmelos Gum)

\section{Scanning electron microscopy}

The SEM images of Rosuvastatin Calcium, Physical Mixture and the solid dispersion are shown in below.

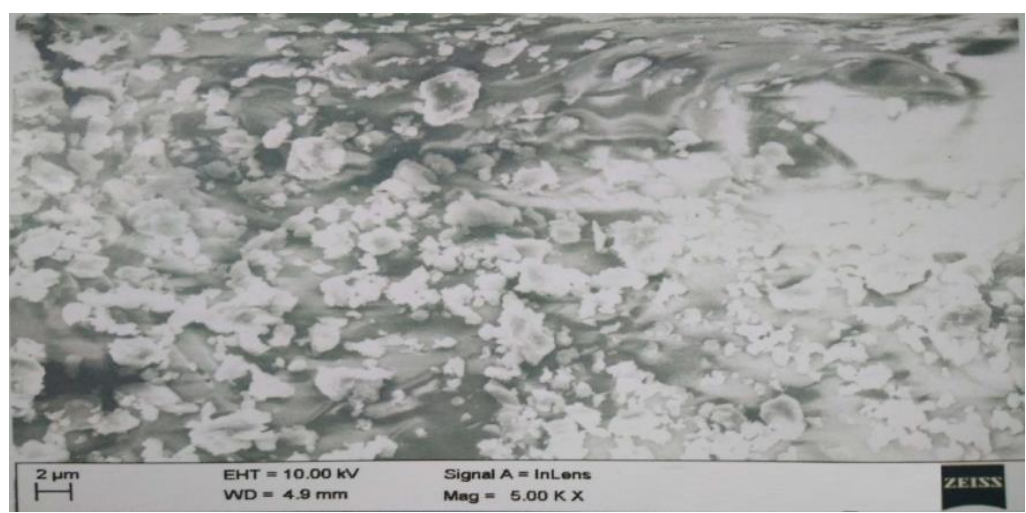

Fig. 8: Scanning electron micrograph of rosuvastatin calcium 


\section{X-ray Diffraction Studies}

$\mathrm{X}$-ray studies were carried out of Rosuvastatin Calcium, optimized solid dispersion. X-ray diffraction of Rosuvastatin calcium shows characteristics peaks at 18.02 , 22.54 which confirmed its crystalline nature. The X-ray diffraction of Solid dispersion exhibited the characteristic peaks of Drug, but with lower intensities. This indicates the formation of amorphous drug within crystalline polymer matrix. $^{20,21}$

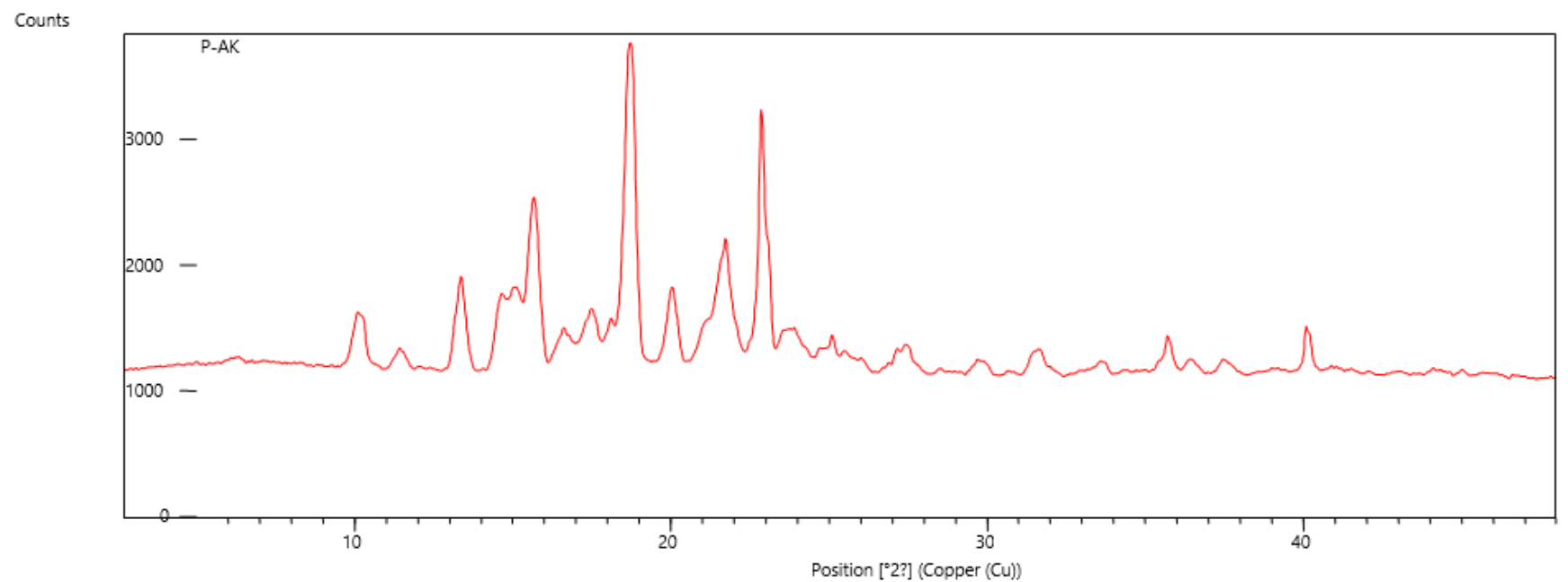

Fig. 9: X- ray diffraction of rosuvastatin calcium

\section{Fast dissolving tablets of rosuvastatin calcium}

Fast dissolving tablets of Rosuvastatin Calcium was prepared using different excipients i.e., superdisintegrants, binders, lubricants and ten evaluated for various parameters to select the best combination to prepare Rosuvastatin Calcium tablets. Superdisintegrants play important role in case of fast dissolving tablets as they subject the tablet disintegrate in proper time to get its effect. The incorporation of superdisintegrant in the solid dispersion tablets can also strongly enhance the dissolution rate of the lipophillic drug. From the dissolution profile of solid dispersion it was concluded that the SD9 show maximum cumulative drug release in 1 hour. So the SD9 was selected for the preparation of fast dissolving tablets. Different trials were taken to formulate an optimized formulation with sufficient mechanical strength, disintegration time and dissolution profile. Table 7 shows the different trials, which were undertaken for formulating FDTs. ${ }^{22-23}$

Table 12: Composition of various ingredients used to prepare FDTs

\begin{tabular}{|l|l|l|l|l|l|l|l|l|l|l|}
\hline S.no & Ingredients(mg) & F1 & F2 & F3 & F4 & F5 & F6 & F7 & F8 & F9 \\
\hline 1 & Solid Dispersion & 20 & 20 & 20 & 20 & 20 & 20 & 20 & 20 & 20 \\
\hline 2 & SSG & 15 & 15 & 15 & 18 & 18 & 18 & 21 & 21 & 21 \\
\hline 3 & MCC & 30 & 37.5 & 45 & 30 & 37.5 & 45 & 30 & 37.5 & 45 \\
\hline 4 & Mag.Stearate & 1.5 & 1.5 & 1.5 & 1.5 & 1.5 & 1.5 & 1.5 & 1.5 & 1.5 \\
\hline 5 & Talc & 3 & 3 & 3 & 3 & 3 & 3 & 3 & 3 & 3 \\
\hline 6 & Lactose & 80.5 & 73 & 65.5 & 77.5 & 70 & 62.5 & 71.5 & 67 & 59.5 \\
\hline 7 & Total (mg) & 150 & 150 & 150 & 150 & 150 & 150 & 150 & 150 & 150 \\
\hline
\end{tabular}

For the preparation of Fast Dissolving Tablets of Rosuvastatin Calcium, various excipients were screen for the best formulation and their concentrations were optimized thereafter. In earlier studies it was suggested that the sodium starch glycolate has positive impact on the disintegration time of solid dispersion of various poorly soluble drugs increasing their dissolution rate. So the SSG selected as superdisintegrant in the present study.

The batches F1 to F9 were prepared and the uniform mass was sieve through mesh \#85. The powder mass was also evaluated for angle of repose, bulk density, tapped density, Hausner's ratio and compressibility index. After the evaluation of the powder, tablets were prepared using direct compression method. Microcrystalline cellulose was used as directly compressible material which also has disintegrant property. The prepared tablets were evaluated for hardness, uniformity of weight, thickness, wetting time, wetting ratio, disintegration time, friability, dissolution test. 


\section{Evaluation of fast dissolving tablets}

\section{Pre-compression evaluations for the powder blend}

Pre-compression evaluation studies were carried out to ensure the flow properties of the powder blend. Good flow properties of the powder blend will yield the tablets of desired quality and ease the tableting process. So, it was mandatory to assess the flowbility of the blend before compression. The results of pre-compression evaluation were shown in Table 8 .

Table 13: Pre-compression parameters of Powder Blends

\begin{tabular}{|l|c|c|c|c|c|c|}
\hline S. No. & $\begin{array}{c}\text { Batch } \\
\text { code }\end{array}$ & $\begin{array}{c}\text { Angle of } \\
\text { Repose }\end{array}$ & $\begin{array}{c}\text { Bulk } \\
\text { density }\left(\mathbf{g} / \mathbf{c m}^{\mathbf{3}}\right)\end{array}$ & $\begin{array}{c}\text { Tapped } \\
\text { density }\left(\mathbf{g} / \mathbf{c m}^{\mathbf{3}}\right)\end{array}$ & $\begin{array}{c}\text { Hausner's } \\
\text { ratio }\end{array}$ & $\begin{array}{c}\text { Compressibility } \\
\text { index \% }\end{array}$ \\
\hline 1 & F1 & 30.19 & 0.2987 & 0.3671 & 1.179 & 16.57 \\
\hline 2 & F2 & 27.94 & 0.3091 & 0.3599 & 1.178 & 16.40 \\
\hline 3 & F3 & 29.11 & 0.3001 & 0.3665 & 1.179 & 16.39 \\
\hline 4 & F4 & 31.04 & 0.3087 & 0.3569 & 1.177 & 16.39 \\
\hline 5 & F5 & 32.87 & 0.3127 & 0.3601 & 1.179 & 16.51 \\
\hline 6 & F6 & 32.32 & 0.3030 & 0.3665 & 1.177 & 16.49 \\
\hline 7 & F7 & 25.67 & 0.3026 & 0.3811 & 1.181 & 16.54 \\
\hline 8 & F8 & 30.01 & 0.3101 & 0.3891 & 1.180 & 16.54 \\
\hline 9 & F9 & 31.76 & 0.3212 & 0.3671 & 1.182 & 16.57 \\
\hline
\end{tabular}

\section{Post compression evaluations}

The tablets obtained after compression were evaluated on various parameters to determine their quality and to ensure that the resultant product meets all necessary criteria's required for the fast dissolving tablets.

Table 14: Post compression parameters of prepared formulation

\begin{tabular}{|l|c|c|c|c|c|c|c|}
\hline $\begin{array}{l}\text { S. } \\
\text { No. }\end{array}$ & $\begin{array}{c}\text { Batch } \\
\text { code }\end{array}$ & $\begin{array}{c}\text { Disintegration } \\
\text { time (seconds) }\end{array}$ & $\begin{array}{c}\text { Hardness } \\
\mathbf{( k g / \mathbf { c m } ^ { 3 } )}\end{array}$ & $\begin{array}{c}\text { Friability } \\
(\boldsymbol{\%} \mathbf{w} / \mathbf{w})\end{array}$ & $\begin{array}{c}\text { Wetting } \\
\text { time } \\
(\mathbf{s e c o n d s})\end{array}$ & $\begin{array}{c}\text { Water } \\
\text { absorption } \\
\text { ratio (\% w/v) }\end{array}$ & $\begin{array}{c}\text { Drug content } \\
(\boldsymbol{\%})\end{array}$ \\
\hline 1 & F1 & $90 \pm 5$ & $3.2 \pm 1.0$ & 0.78 & 37 & 40.49 & 101.51 \\
\hline 2 & F2 & $87 \pm 5$ & $3.3 \pm 1.0$ & 0.76 & 33 & 41.44 & 89.81 \\
\hline 3 & F3 & $90 \pm 5$ & $3.3 \pm 1.2$ & 0.83 & 39 & 43.45 & 104.43 \\
\hline 4 & F4 & $62 \pm 5$ & $3.0 \pm 1.1$ & 0.82 & 40 & 41.98 & 103.08 \\
\hline 5 & F5 & $60 \pm 5$ & $3.4 \pm 1.2$ & 0.76 & 35 & 43.01 & 98.79 \\
\hline 6 & F6 & $60 \pm 5$ & $3.0 \pm 1.3$ & 0.79 & 33 & 45.21 & 109.65 \\
\hline 7 & F7 & $40 \pm 5$ & $3.5 \pm 1.5$ & 0.69 & 39 & 41.90 & 105.22 \\
\hline 8 & F8 & $40 \pm 5$ & $3.1 \pm 1.2$ & 0.81 & 36 & 42.99 & 108.94 \\
\hline 9 & F9 & $40 \pm 5$ & $3.2 \pm 1.0$ & 0.82 & 40 & 43.56 & 99.51 \\
\hline
\end{tabular}

The probable reason for the better results with F7 batch might be due to the amount of superdisintegrant used in the formulations.

Table 15: Post compression parameters of formulation (F7)

\begin{tabular}{|l|c|}
\hline Evaluation parameters & Results \\
\hline Hardness & $3.5 \pm 1.5 \mathrm{~kg} / \mathrm{cm}$ \\
\hline Diameter & $12 \pm 1 \mathrm{~mm}$ \\
\hline Thickness & $6 \pm 2 \mathrm{~mm}$ \\
\hline Weight variation test & Complies $( \pm 5 \%)$ \\
\hline Drug content & Complies $(105.22)$ \\
\hline Friability & $0.69 \%$ \\
\hline Wetting time & $39 \mathrm{sec}$ \\
\hline Water absorption ratio & $41.90 \%$ \\
\hline Disintegration & $40 \pm 5$ \\
\hline
\end{tabular}

\section{Dissolution studies}

The dissolution studies were performed to evaluate the release profile of the drug, which relates the percentage of drug release from its dosage form with the function of time. The percentage cumulative release of fast dissolving tablet and marketed tablets of Rosuvastatin Calcium is shown in figure.21. 
Table 16: Percentage cumulative release of fast dissolving tablets of Rosuvastatin Calcium and Marketed tablets of Rosuvastatin Calcium

\begin{tabular}{|c|c|c|c|}
\hline S.No. & $\begin{array}{c}\text { Time } \\
(\mathbf{m i n})\end{array}$ & $\begin{array}{c}\text { \% Cumulative drug release of FDT } \\
\text { of Rosuvastatin Calcium }\end{array}$ & $\begin{array}{c}\text { \% Cumulative drug release of Marketed } \\
\text { tablet of Rosuvastatin Calcium }\end{array}$ \\
\hline 1 & 0 & 13.5759 & 10.7473 \\
\hline 2 & 5 & 77.6799 & 44.762 \\
\hline 3 & 10 & 83.2538 & 49.5103 \\
\hline 4 & 15 & 86.7993 & 52.0978 \\
\hline 5 & 20 & 91.519 & 55.3411 \\
\hline 6 & 30 & 97.6765 & 57.4437 \\
\hline
\end{tabular}

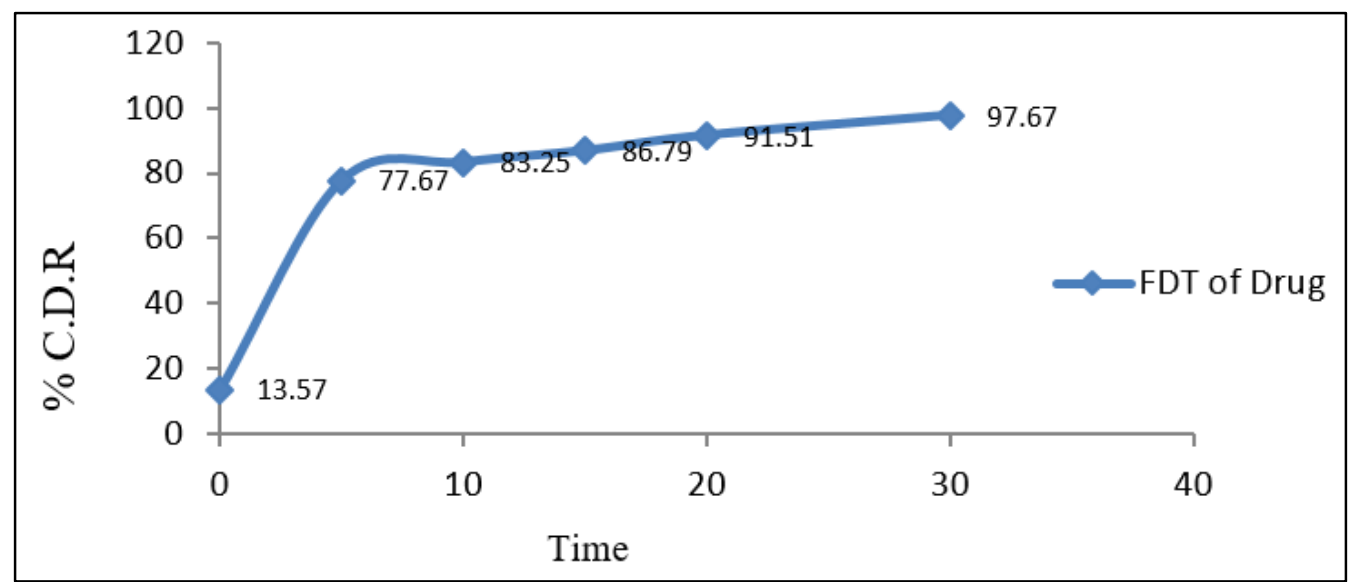

Fig. 20: Percentage cumulative release of fast dissolving tablet of Rosuvastatin Calcium



Fig. 21: Dissolution profile of the pure drug, fast dissolving tablet of Rosuvastatin Calcium (F7) and Marketed tablet of Rosuvastatin Calcium

From the dissolution studies, it can be concluded that the dissolution rate of the drug of the marketed tablets was low as compared to the fast dissolving tablets of the Rosuvastatin Calcium prepared by direct compression method after the formulation of solid dispersions. Table shows that of fast dissolving tablets of solid dispersion of Rosuvastatin Calcium with sodium starch glycolate as super-disintegrant releases $77.67 \%$ drug in just 5 minutes and $97.67 \%$ in 30 minutes which is quite higher than the marketed tablets of Rosuvastatin Calcium. ${ }^{24}$ 


\section{Mathematical models}

Table 17: Fitting of drug release from prepared fast dissolving tablets to various release kinetic models

\begin{tabular}{|l|c|c|c|c|c|c|c|c|c|c|}
\hline Mechanism & \multicolumn{2}{|c|}{ Zero-order } & \multicolumn{2}{c|}{ First-order } & \multicolumn{2}{c|}{ Higuchi } & \multicolumn{2}{c|}{$\begin{array}{c}\text { Hixson- } \\
\text { Crowell }\end{array}$} & \multicolumn{2}{c|}{$\begin{array}{c}\text { Korsemeyer- } \\
\text { Peppas }\end{array}$} \\
\hline F7 & Slope & $\mathrm{R}^{2}$ & Slope & $\mathrm{R}^{2}$ & Slope & $\mathrm{R}^{2}$ & Slope & $\mathrm{R}^{2}$ & Slope & $\mathrm{R}^{2}$ \\
\cline { 2 - 11 } & 0.6777 & 0.943 & 0.003 & 0.978 & 0.133 & 0.989 & 0.013 & 0.982 & 25.20 & 0.965 \\
\hline
\end{tabular}

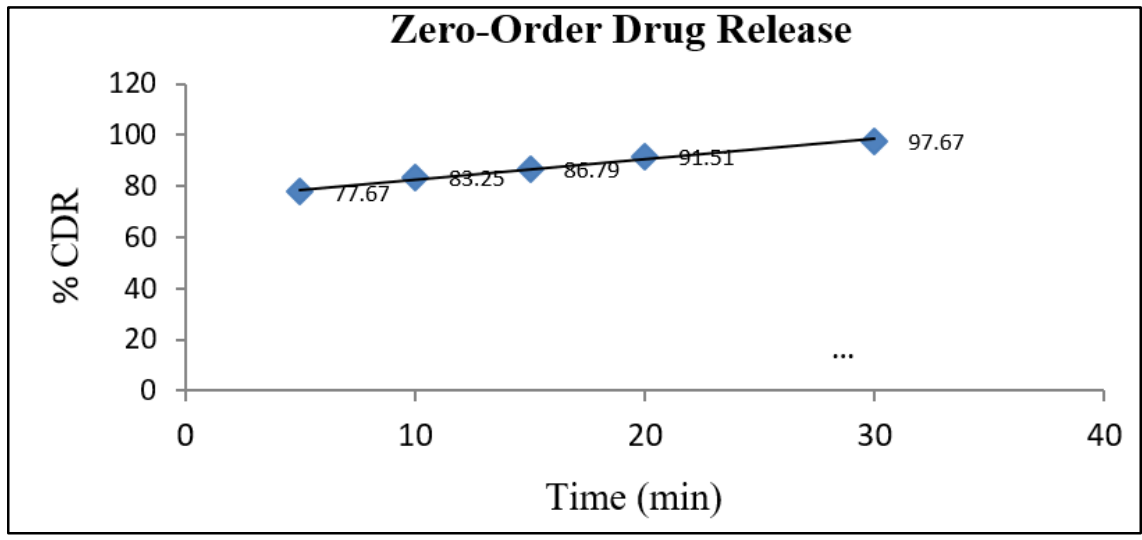

Fig. 22: Zero order release of fast dissolving tablets

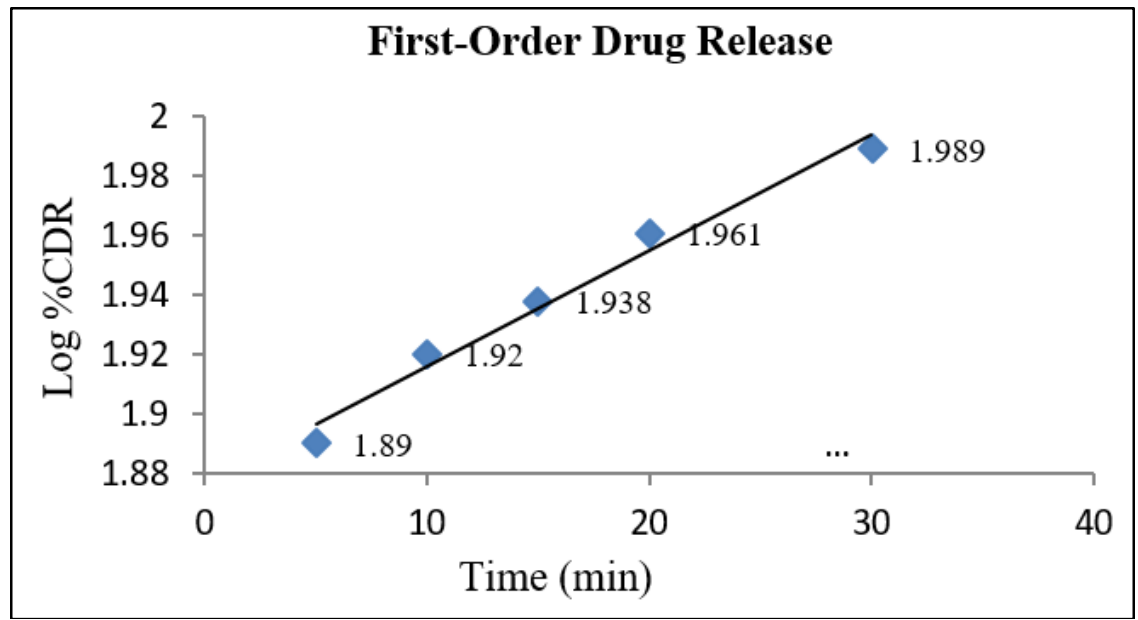

Fig. 23: First order release fast dissolving tablets

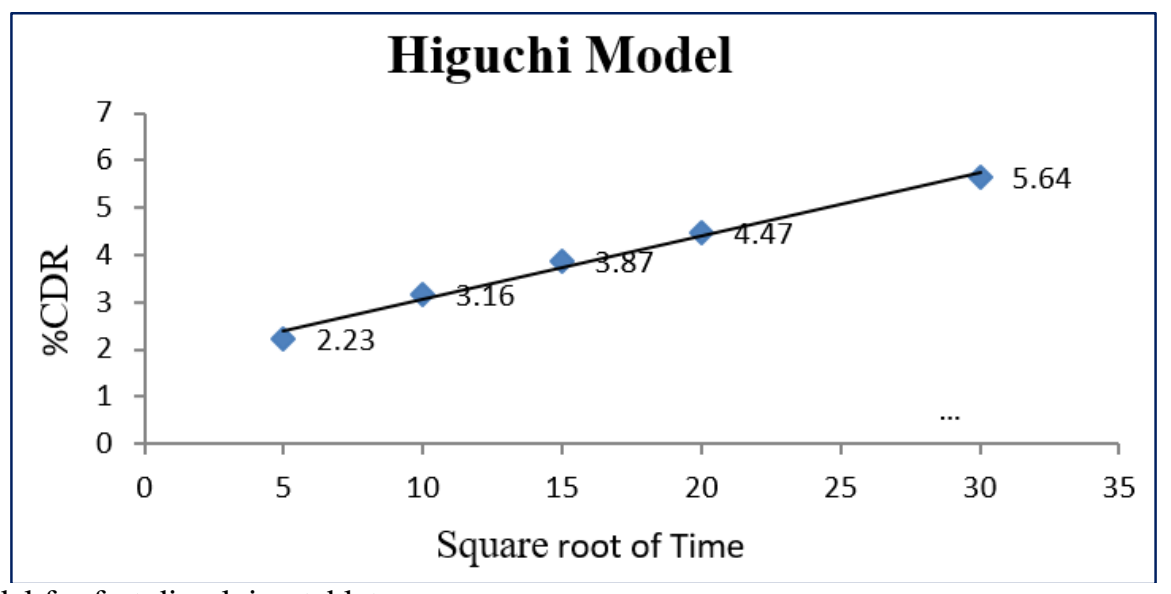

Fig. 24: Higuchi model for fast dissolving tablets 


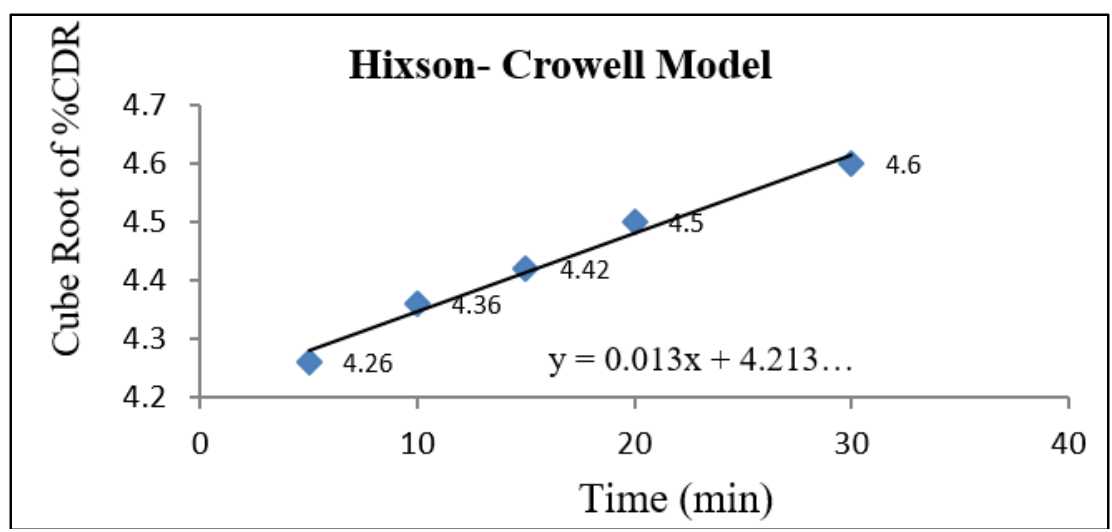

Fig. 25: Hixson-Crowell model for fast dissolving tablets

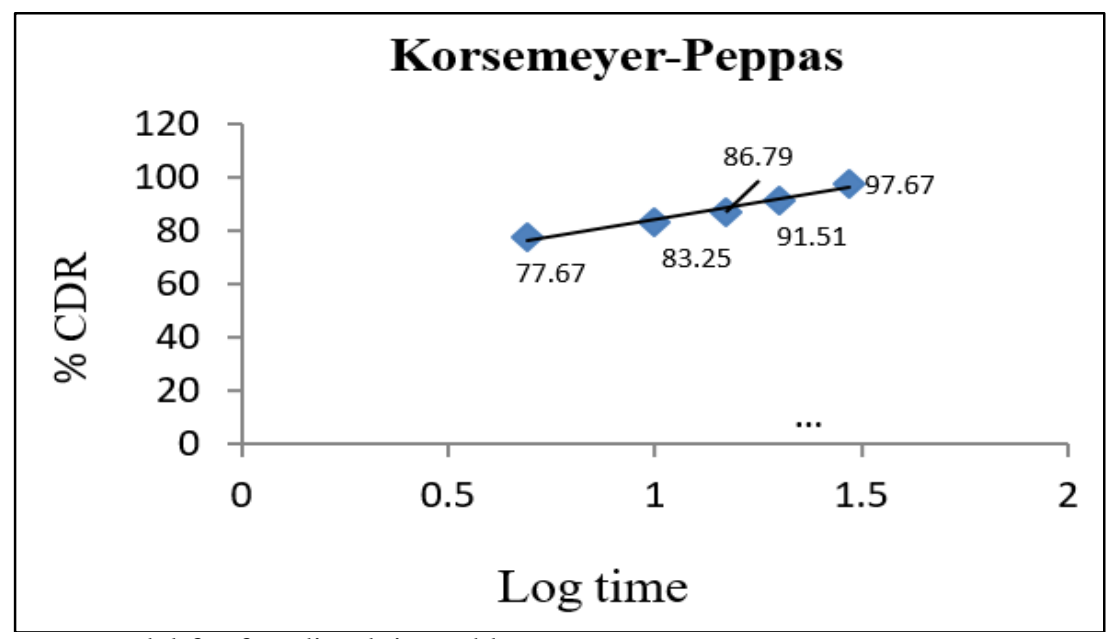

Fig. 26: Korsemeyer-Peppas model for fast dissolving tablet

Table 18: Various Parameters used to calculate the drug release from FDTs.

\begin{tabular}{|c|c|c|c|c|}
\hline Time & Log time & Square of time & \%CDR & Log \% CDR \\
\hline 5 & 0.698 & 2.23 & 77.67 & 1.89 \\
\hline 10 & 1.0 & 3.16 & 83.25 & 1.92 \\
\hline 15 & 1.176 & 3.87 & 86.79 & 1.938 \\
\hline 20 & 1.3 & 4.47 & 91.51 & 1.961 \\
\hline 30 & 1.477 & 5.64 & 97.67 & 1.989 \\
\hline
\end{tabular}

The $\mathrm{R}^{2}$ value was found to be highest for Higuchi model i.e., 0.989 which indicates that the polymer formed a hydrophilic matrix in which drug gets entrapped in an amorphous form. As the matrix depletes, the drug in the amorphous form is available for dissolution. ${ }^{25}$

\section{Summary and Conclusion}

Aim of the present investigation was to enhance the solubility and dissolution rate of Rosuvastatin Calcium. Solid dispersions of Rosuvastatin Calcium were prepared by using A.Marmelos, as carriers in different ratios through solvent evaporation method. On the basis of maximum percentage drug release the optimized formulation of solid dispersion of Rosuvastatin Calcium was characterized by various analytical methods. The fast dissolving tablets of the optimized solid dispersion were prepared and evaluated for various parameters. The tablets were evaluated for various pharmacopeial tests. A released kinetic data through mathematical tools indicated the drug release follow
Higuchi model, which indicates that the carrier formed a hydrophilic matrix in which drug gets entrapped in an amorphous form. As the matrix depletes, the drug in the amorphous form is available for dissolution. Thus, it can be concluded that the solid dispersion technology can be used as that alternative to produced fast tablets especially for drugs having poor water solubility.

\section{Acknowledgement}

The authors are highly thankful to all staff members of Rayat-Bahra Institute of Pharmacy, Education City, Hoshiarpur, Punjab, India and University School of Pharmaceutical Sciences, Rayat-Bahra University, Mohali, Punjab, India for their constant encouragement and support 
for preparing this article. The authors hereby declare no conflict of Interest.

\section{Source of funding}

None.

\section{Conflict of interest}

None.

\section{Reference}

1. Amidon GL, Lennernas H, Shah VP, Crison JR. A theoretical basis for a biopharmaceutices drug classification: The correlation of in-vitro drug product dissolution and in vivo bioavailability. Pharm Res 1995;12:413-20.

2. Aulton M. Pharmaceutics: The science of dosage form design. 1st ed. London; Churchill Livingstone 1996;14:81-6.

3. Aurora J, Pathak V. Oral disintegrating technologies: oral disintegrating dosage forms: an overview. Drug Deliv Technol 2005;5:50-4.

4. Badwan AA, Khordagui LK, Saleh AK, Khalil SA. The solubility of benzodiazepines in sodium salicylate solution and propsed mechanism for hydrotropic solubilization. Int $J$ Pharmaceutices. 1983;13:67-74.

5. Bahlul Z Awen, Varun Dasari, Babu Rao Chandu, Mukkanti Khagga. New UV-Spectrophotometeric method for the estimation of Valganciclovir in bulk and its formulation. Int $J$ Pharm Studies Res 2011;2(1):1-4.

6. Chamarthi R P Kishore, GV Krishna Mohan. Structrural indentification and estimation of Rosuvastatin calcium. J Anal Chem Res 2017;(12):17-27.

7. Chranjib DB, Jayakar B. Design and charcterisation of fast dissolving tablets of telmisartan. Int $\mathrm{J}$ Pharma Recent Res 2009;1:31-40.

8. Patil D N, Kulkarni AR, Patil BS. Fruit Gum of Aegle marmelos as Pharmaceutical Aid. Int J Pharm 2010;6(1):6871.

9. Divya G Panicker, Rajesekar an Prasama, Ramallingam Kalaichelvi, E Kambaram. Method Development and Validation for the Estimation of Aprepitant in Capsules by UPLC. J Pharma Res 2012;4998-5000.

10. Deokar TG, Power SS, Jadhav MG. Fesem and FTIR spectroscopic characterization of Aegle marmelos unripe fruit. Int Res J Bio Sci 2017;6(1):34-9.

11. Faiza Fahim, Ayesha Naseer, Shakil Ahmed. A Green Approach for the Determination of Selected Anti-Diabetic Drugs in Pharmaceutical Formulation. Journal of Brazil Chemical Sciences. 2014;25(11):1-6.
12. Guo Y, Luo J, Tan S, Otieno BO, Zhang Z. The applications of Vitamin E TPGS in drug delivery. Eur J Pharm Sci 2013;49(2):175-86.

13. Indian Pharmacopoeia. Buffer solutions. 2007;1:480.

14. Jaydeep Patel, Garala Kevin, Anjali Patel, Mihir Raval, Navin Sheth. Development of the UV-Spectrophotometric method of Olmesartan medoxomil in bulk drug and pharmaceutical formulation and stress degradation studies. Pharm Methods 2011;2(1):36-41.

15. Kumar A, Sahoo SK, Patil. Formulation and Evaluation of mouth Dissolving Tablets of Fenofibrate using Sublimation Technique. Int J Chem Technol Res 2009;(4):840-50.

16. Lipinski CA, Lombardo. Experimental and computational approaches to estimate solubility and permeability in drug discovery and development settings. Adv Drug Deliv Rev 2011;46:3-26

17. Neuberg C. Hydrotropy. Biochemical J Pharm. 1989;75:577.

18. Rezowanur Rahman, Asaduzzaman SM, Ashraful Islam. Development and Validation of UV Spectrophotometric Method for Determination of Cefurixime in Pharmaceutical Dosage forms. J Pharma-Tech Res 2012;2(4):351-8.

19. Parthar Atul N, Desai Nilesh V, Ranage Akkatai A, Kalekar Kamlakar S. A review on Aegle marmelos: A Potential Medicinal Tree. Int Res J Pharm 2012;3(8):86-91.

20. P Geetha Swarupa, D Radha Krishna, KRS Prasadk, Suresh Babu. Stability indicating method development and validation for the estimation of aprepitant by RP-HPLC in bulk and pharmaceutical dosage form. Scholars Res Libr 2015;264-71.

21. Rampure MV, Raju SA, Shirsand SB, Swany PV, Nagendrakumar D, Basawaraj B, et al. Formulation and Evaluation of Ordodispersible Tablets of Alfuzosin. International Journal Pharmaceutical Technology Research. 2010;2(1):84-8.

22. R. Bansal, A. Guleria, P.C. Acharya. FT-IR Method Development and Validation for Quantitative Estimation of Zidovudine in Bulk and Tablet Dosage Form. 2013;63:165-70.

23. Biradar S S, Bhagavati S T, Kuppasad I J. Fast Dissolving Drug Delivery Systems: A Brief Overview. Int J Pharmacol. 2006;4(2).

24. Tabbouche OS. Validation of a UV-Spectrophotometeric method for the assay paracetamol in solutions. Int J Pharm 2013;3(1):24-7.

25. Vidya Bhushan Kuruwanshi, Pratibha Katiyar, Shabnam Khan. Scientific Approaches of Gum Karaya for High Gum Production. Int J Microbiol Appl Sci 2017;6(8):3366-74.

26. Yuvraj Dilip Dange, Sandip Mohan Hommane, Somnath Devidas Bhinge, Vijay Rajaram Salunkhe, Dhanraj Raghunath Jadge. Development and validation of UV-Spectrophotometeric method for estimation of metformin in bulk and tablet dosage form. Indian J Pharma Edu Res 2017;51(4s):s754-s60. 